\title{
Comparative Study on Marshall Characteristics of Bituminous Mixes by Partial Replacement of Foundry Sand and Ceramic Tile Dust as Fine Aggregate
}

\author{
Gazi Mohammad Harun-Or-Rashid”, Abdullah Al Mamun, Isfaq Eashir Epu \\ Department of Civil Engineering, Rajshahi University of Engineering \& Technology, Rajshahi, Bangladesh \\ Email address: \\ gmharun.ruet11@gmail.com (G. M. Harun-Or-Rashid), abdullahasiya117@gmail.com (A.A1 Mamun), epu130055@gmail.com (I. E. Epu) \\ ${ }^{*}$ Corresponding author
}

To cite this article:

Gazi Mohammad Harun-Or-Rashid, Abdullah Al Mamun, Isfaq Eashir Epu. Comparative Study on Marshall Characteristics of Bituminous Mixes by Partial Replacement of Foundry Sand and Ceramic Tile Dust as Fine Aggregate. American Journal of Materials Synthesis and Processing. Vol. 5, No. 1, 2020, pp. 10-16. doi: 10.11648/j.ajmsp.20200501.12

Received: August 15, 2020; Accepted: September 14, 2020; Published: September 24, 2020

\begin{abstract}
Bituminous hot mixes for flexible pavement construction are the most widely used throughout the world. Mainly aggregate, sand, bitumen and filler are used for flexible pavement construction. But in case of filler, engineers are divided according to their choice depending on the availability of materials and environmental condition. In this investigation an attempt is made to investigate the properties of bituminous pavement materials by the partial replacement of spent foundry sand and ceramic tile dust individually as fine aggregate with an increment of $10 \%$. Actually Foundry sand is a high quality silica sand and it is used to form molds for ferrous (iron and steel) and non-ferrous (copper, aluminum, brass etc.) metal castings. A huge quantity of foundry sand is used by metal casting industries every year and disposed them after being used. On the other hand two sources are available for ceramic wastes. Ceramic's industry is the first source and second is the construction sight of ceramic's work. A huge quantity of ceramic wastes are produced from these sources and if these wastes can be utilized in pavement construction, the disposal and pollution problem can be minimized. The main target of this investigation is to determine optimum bitumen content (OBC) and suitable mix to ensure a durable and cost effective pavement after being partial replacement of foundry sand and ceramic tile dust. The proposed mix design will be conducted in accordance with Marshall Mix design. After performing the experimental investigation it is found that for $30 \%$ replacement of waste foundry sand and higher percentage of ceramic tile dust provide superior field performance and better stability than the conventional mixes.
\end{abstract}

Keywords: Foundry Sand, Ceramic Tile Dust, Marshall Mix Design, Aggregate Properties, Optimum Bitumen Content

\section{Introduction}

Bituminous roads are defined as the roads in the construction of which bitumen is used as binder. Most of the roads in the world are constructed using bitumen, as these roads are so useful. The term bituminous mix refers to a mix in which the aggregates are bounded together by bituminous material. Mix design is the method to determine that whether a suitable mixture can be prepared with the available materials and to determine the best combination of these materials for optimum performance Bituminous mix consists of an intimate mixture of aggregates and bitumen. The two steps in the mix design procedure are material evaluation and mix design. The objective of the material evaluation process is to determine the important properties of the component materials to come up with an optimum blend of materials to meet the mix requirements. The objective of the mix design step is to determine the type and percentage of bituminous binder with the help of results from compacted test mixes.

In bituminous mixes, coarse aggregates give stability through interlocking of the aggregate particles which contribute to frictional resistance to displacement. They provide the framework to distribute or "spread" the stresses created by wheel loads acting on the wearing surface so that stresses transmitted to the sub-grade will not be sufficiently great to result in excessive deformation or displacement of that foundation layer. Through interlocking of the particles, the fine aggregates give some additional stability to the mix 
and at the same time fine aggregates reduce the voids in the coarse aggregates.

The function of filler in the mixes is to fill the excess voids in mineral aggregates. When filler is added an increase in the viscosity of the bitumen-filler mixture occurs and the bitumen becomes plastics. The workability of a mix depends, to some extent, on the amount and type of filler present in the mix. The binder acts as a lubricant during compaction and then serves to keep the frame work of aggregates in position by the cohesion it provides.

The objective for the design of bituminous mix is to determine a logical and economical blend and gradation of aggregates with the corresponding bitumen content. The two fundamental properties of bituminous paving mixture which are held to be of utmost importance are stability and durability. It means the pavement made of this type of mix should be capable of resisting undue deformation under moving wheel loads and severe action of air, temperature and rainfall.

In the past a number of research work has been done to make use of Foundry sand and Ceramic tile dust into the bituminous mix to make it cost effective. Some researchers have been performing researches by using different percentages of Foundry sand and Ceramic tile dust with the fresh mixes to improve the physical property of bituminous mixes. In a study it was represented that by replacing some percentages like $0,25,30,35,40,75$ with foundry sand to prepare bituminous mold and the Marshall Stability test has been carried out to find out optimum percentage of foundry sand and bitumen. And the results shows that foundry sand has satisfactory improvement on bituminous concrete mix [7]. In another study it shows that the concrete with foundry sand is capable to resist the winter conditions better than any other materials suitable for pavement construction [4]. In this paper, it is proposed that the environmental effects and disposal problems can be reduced by using foundry sand in pavement construction and cost is also reduced [3]. Hariharan K et al., 2018 also represented that the partial replacement of $15 \%$ Quarry dust with waste foundry sand can be used as a good alternative for aggregate [5]. Bekir and Aslan, 2017 showed that for optimum bitumen content Marshall Stability values significantly increases with waste foundry sand addition in the mixture replace of mineral aggregate [9]. Compare the compressive strength and durability properties of concrete by replacing $20 \%$ cement with ceramic waste [12]. Fly ashes along with conventionally used stone dust are used as filler in bituminous concrete and comparison is made between them. The results show that all fly ashes are good as filler and can be used in bituminous construction up to $7 \%$ and also fly ash group rich in calcium oxide gave better results [15]. Reduction of optimum bitumen content in bituminous mixes using plastic coated aggregates which results in economic in construction of bituminous concrete and also solve disposal problem of plastic waste [16]. Study is done to investigate the effects of using crushed ceramic in the production of interlocking paving units [14]. Use of ceramic wastes in concrete production with the aim of reducing cement and fine aggregate content [13]. A study on effect of ceramic waste in bituminous concrete mixes [11]. A study on effect of waste ceramic tiles in flexible pavement [10].

\section{Laboratory Investigation}

For this research purpose the Foundry sand was collected from foundry shop of RUET and Ceramic tile dust was collected from local construction site. Specific gravity and unit weight of fresh sand, Foundry sand and Ceramic tile dust are shown in table 1 .

Table 1. Properties of fine aggregate.

\begin{tabular}{lllll}
\hline Properties & Method (AASHTO & \multicolumn{3}{c}{ Soundry Ceramic } \\
and BS) & sand & tile dust \\
\hline Unit weight, loose, $\mathrm{kg} / \mathrm{m}^{3}$ & $\mathrm{~T} 19$ & 1430 & 1448 & 1398 \\
Unit weight, dense, $\mathrm{kg} / \mathrm{m}^{3}$ & $\mathrm{~T} 19$ & 1570 & 1603 & 1552 \\
Bulk specific gravity & $\mathrm{T} 85$ & 2.28 & 2.63 & 2.32 \\
Apparent specific gravity & $\mathrm{T} 85$ & 2.52 & 2.76 & 2.56 \\
\hline
\end{tabular}

\subsection{Mix Design}

To investigate the behavior of bituminous mixes with different fine aggregates, dense graded bituminous mix is essential. In the dense graded bituminous mix, the aggregate blend is designed to be evenly graded from coarse to fine so as to arrive at a dense mix with a controlled void content, hence producing a stable and durable paving. The main objective of the investigation was to make a comparative study of bituminous mixes with different fine aggregates, Coarse aggregate and filler.

Depending upon the types of fine aggregates used in the mix, following mixes were used in the present investigation:

Mix A1: in which fresh FA is $100 \%$

Mix A2: in which fresh FA is $90 \%$ and $10 \%$ foundry sand. Mix A3: in which fresh FA is $80 \%$ and $20 \%$ foundry sand. Mix A4: in which fresh FA is $70 \%$ and $30 \%$ foundry sand. Mix A5: in which fresh FA is $60 \%$ and $40 \%$ foundry sand. Mix A6: in which fresh FA is $50 \%$ and $50 \%$ foundry sand. Mix B1: in which fresh FA is $100 \%$

Mix B2: in which fresh FA is $90 \%$ and $10 \%$ ceramic dust. Mix B3: in which fresh FA is $80 \%$ and $20 \%$ ceramic dust. Mix B4: in which fresh FA is $70 \%$ and $30 \%$ ceramic dust. Mix B5: in which fresh FA is $60 \%$ and $40 \%$ ceramic dust. Mix B6: in which fresh FA is $50 \%$ and $50 \%$ ceramic dust.

Table 2. Percentage of composition in Foundry sand.

\begin{tabular}{ll}
\hline Constituents & Value (\%) \\
\hline $\mathrm{SiO}_{2}$ & 87.91 \\
$\mathrm{Al}_{2} \mathrm{O}_{3}$ & 4.70 \\
$\mathrm{Fe}_{2} \mathrm{O}_{3}$ & 0.94 \\
$\mathrm{CaO}$ & 0.14 \\
$\mathrm{MgO}$ & 0.30 \\
$\mathrm{SO}_{3}$ & 0.09 \\
$\mathrm{Na}_{2} \mathrm{O}_{3}$ & 0.19 \\
$\mathrm{~K}_{2} \mathrm{O}$ & 0.25 \\
$\mathrm{TiO}_{2}$ & 0.15 \\
\hline
\end{tabular}




\begin{tabular}{ll}
\hline Constituents & Value (\%) \\
\hline $\mathrm{SrO}$ & 0.03 \\
$\mathrm{LOI}$ & 5.15 \\
\hline
\end{tabular}

Source: Geo-structural engineering and testing Services, Baroda

Table 3. Percentage of composition of ceramic dust.

\begin{tabular}{llll}
\hline Sl. No. & Oxides & Range (\%) & Typical value (\%) \\
\hline 1 & $\mathrm{SiO} 2$ & $62.0-88.0$ & 64.92 \\
2 & $\mathrm{Al} 2 \mathrm{O} 3$ & $22.0-28.0$ & 25.19 \\
3 & $\mathrm{Fe} 2 \mathrm{O} 3$ & $0.4-0.8$ & 0.7 \\
4 & $\mathrm{TiO} 2$ & $0.6-0.9$ & 0.7 \\
5 & $\mathrm{CaO}$ & $0.2-0.5$ & 0.36 \\
6 & $\mathrm{MgO}$ & $0.4-0.7$ & 0.55 \\
7 & $\mathrm{~K} 2 \mathrm{O}$ & $3.0-5.0$ & 4.50 \\
8 & $\mathrm{Na} 2 \mathrm{O}$ & $2.0-4.0$ & 2.57 \\
\hline
\end{tabular}

Source: www.allstarma.net

\subsection{Marshall Properties}

The maximum load carried by a compacted specimen at a standard test temperature of $60^{\circ} \mathrm{C}$ is defined as Marshall Stability test. The deformation of the Marshall Test specimen that undergoes during the loading upto the maximum load in $0.25 \mathrm{~mm}$ units is the flow value [8]. Hot mix design is applicable for Marshall Stability test using bitumen and aggregates. Marshall Properties like stability, flow value, unit weight, total voids in a mix, voids in mineral aggregates and voids filled with bitumen were found for different percentages bitumen, Foundry Sand and ceramic tile dust. The Graphs were plotted for bitumen content with all the Marshall Properties. To determine the optimum bitumen content (OBC), the bitumen content corresponding to maximum stability, maximum unit weight and $4 \%$ air voids were obtained from these graphs. The optimum bitumen content $(\mathrm{OBC})$ is the average value of bitumen content obtained from the 3 plotted graphs. According to Ministry of Road Transportation Highways (MORTH), the maximum permissible air voids is 3\%-5\% [6]. Marshall Test results and $\mathrm{OBC}$ values for different percentages Foundry Sand content is tabulated in Table 4 and Table 5.

Table 4. Marshall Test results for replacement of foundry sand.

\begin{tabular}{|c|c|c|c|c|c|c|c|c|}
\hline $\begin{array}{l}\text { Aggregate } \\
\text { types }\end{array}$ & OBC (\%) & $\begin{array}{l}\text { Unit Wt. } \\
\left(\mathrm{kg} / \mathrm{m}^{3}\right)\end{array}$ & $\begin{array}{l}\text { Marshall stability } \\
(\mathrm{KN})\end{array}$ & $\begin{array}{l}\text { Flow value } \\
(.25 \mathrm{~mm})\end{array}$ & $\% \mathrm{Va}$ & \%VMA & $\%$ VFB & $\begin{array}{l}\text { Marshall Stiffness } \\
(\mathrm{KN} / \mathrm{mm})\end{array}$ \\
\hline A1 & 5.44 & 2343 & 15.5 & 15.7 & 3.8 & 13.86 & 72 & 3.95 \\
\hline A2 & 5.5 & 2344 & 16 & 14.75 & 4.0 & 14.75 & 74 & 4.34 \\
\hline A3 & 5.51 & 2350 & 16.4 & 14.58 & 4.0 & 15.1 & 75 & 4.43 \\
\hline A4 & 5.53 & 2357 & 16.7 & 13.9 & 3.9 & 15.45 & 76 & 4.48 \\
\hline A5 & 5.57 & 2352 & 14.3 & 13.7 & 4.2 & 14.9 & 72 & 4.17 \\
\hline
\end{tabular}
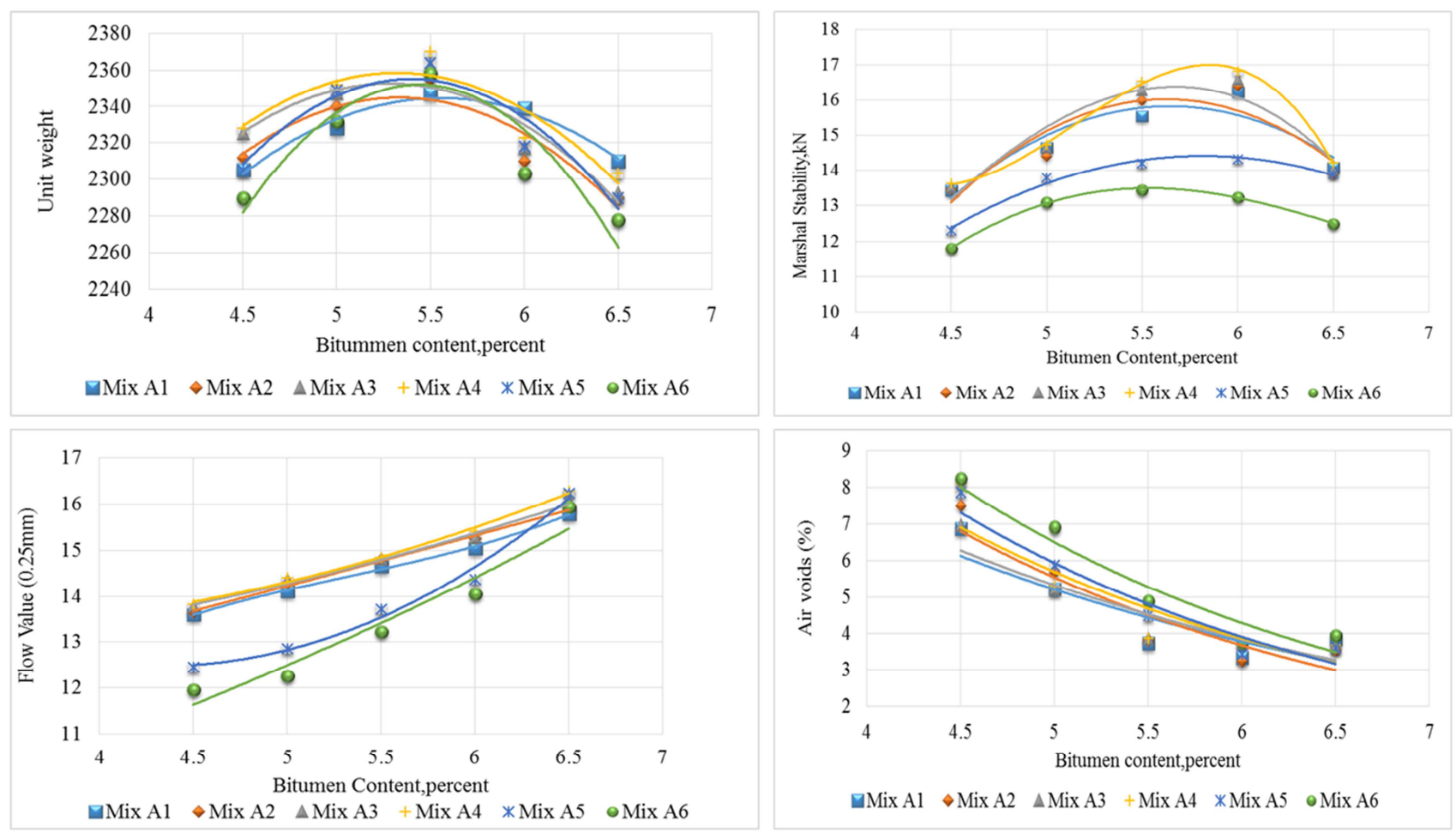

Figure 1. Graphical representations of Marshall Test results for foundry sand replacement. 
Table 5. Marshall Test results for replacement of ceramic tile dust.

\begin{tabular}{|c|c|c|c|c|c|c|c|c|}
\hline Aggregate types & OBC (\%) & $\begin{array}{l}\text { Unit Wt. } \\
\left(\mathrm{kg} / \mathrm{m}^{3}\right)\end{array}$ & $\begin{array}{l}\text { Marshall stability } \\
(\mathrm{KN})\end{array}$ & $\begin{array}{l}\text { Flow value } \\
(0.25 \mathrm{~mm})\end{array}$ & $\% \mathrm{Va}$ & \%VMA & $\%$ VFB & $\begin{array}{l}\text { Marshall Stiffness } \\
(\mathrm{KN} / \mathrm{mm})\end{array}$ \\
\hline B1 & 5.44 & 2343 & 15.5 & 15.7 & 3.8 & 13.86 & 72 & 3.95 \\
\hline B2 & 5.55 & 2328 & 13.55 & 14.10 & 4.00 & 14.40 & 75 & 3.84 \\
\hline B3 & 5.45 & 2352 & 14.54 & 14.50 & 3.51 & 14.40 & 78 & 4.01 \\
\hline B4 & 5.4 & 2348 & 14.10 & 14.60 & 3.60 & 14.55 & 80 & 3.86 \\
\hline B5 & 5.52 & 2347 & 14.50 & 13.80 & 3.80 & 15.60 & 78 & 4.20 \\
\hline
\end{tabular}

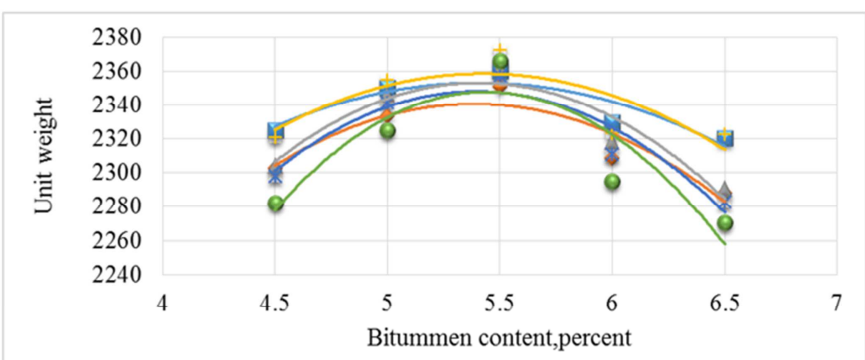

$\square$ Mix B1 $\diamond$ Mix B2 $\Delta$ Mix B3 + Mix B4 $*$ Mix B5 $\odot$ Mix B6

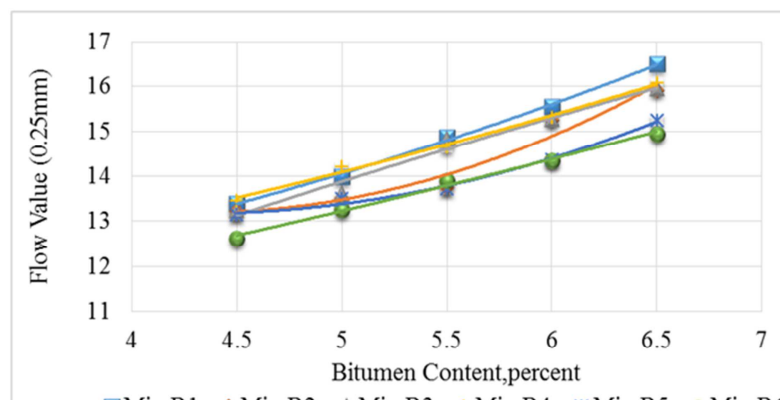

$\square$ Mix B1 $\diamond$ Mix B2 $\triangle$ Mix B3 +Mix B4 $*$ Mix B5 $\bullet$ Mix B6

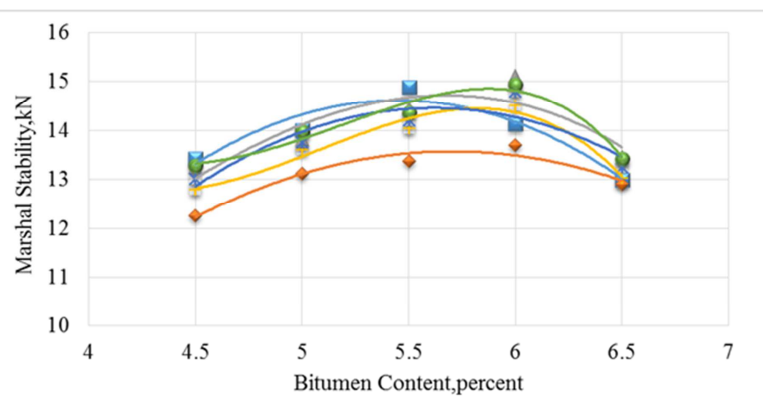

$\square$ Mix $\mathrm{A} \diamond \operatorname{Mix} \mathrm{B} \triangle \operatorname{Mix} \mathrm{C}+\operatorname{Mix} \mathrm{D} * \operatorname{Mix} \mathrm{E} \bullet \operatorname{Mix} F$

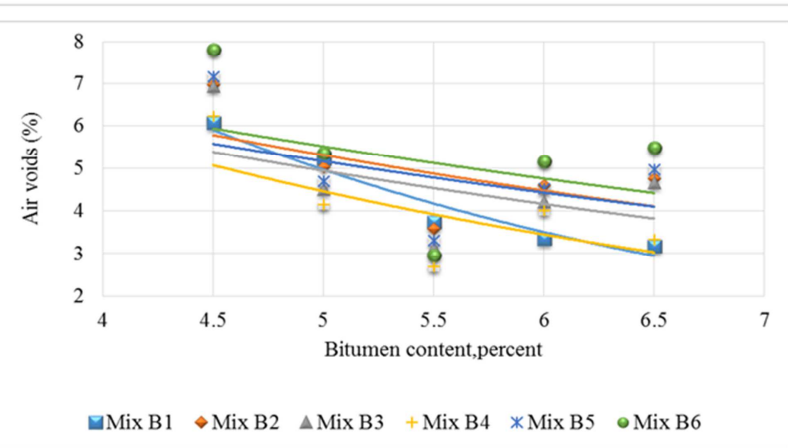

Figure 2. Graphical representations of Marshall Test results for ceramic tile dust replacement.

\subsection{Comparison of Marshall Characteristics of Mix Type A and B}

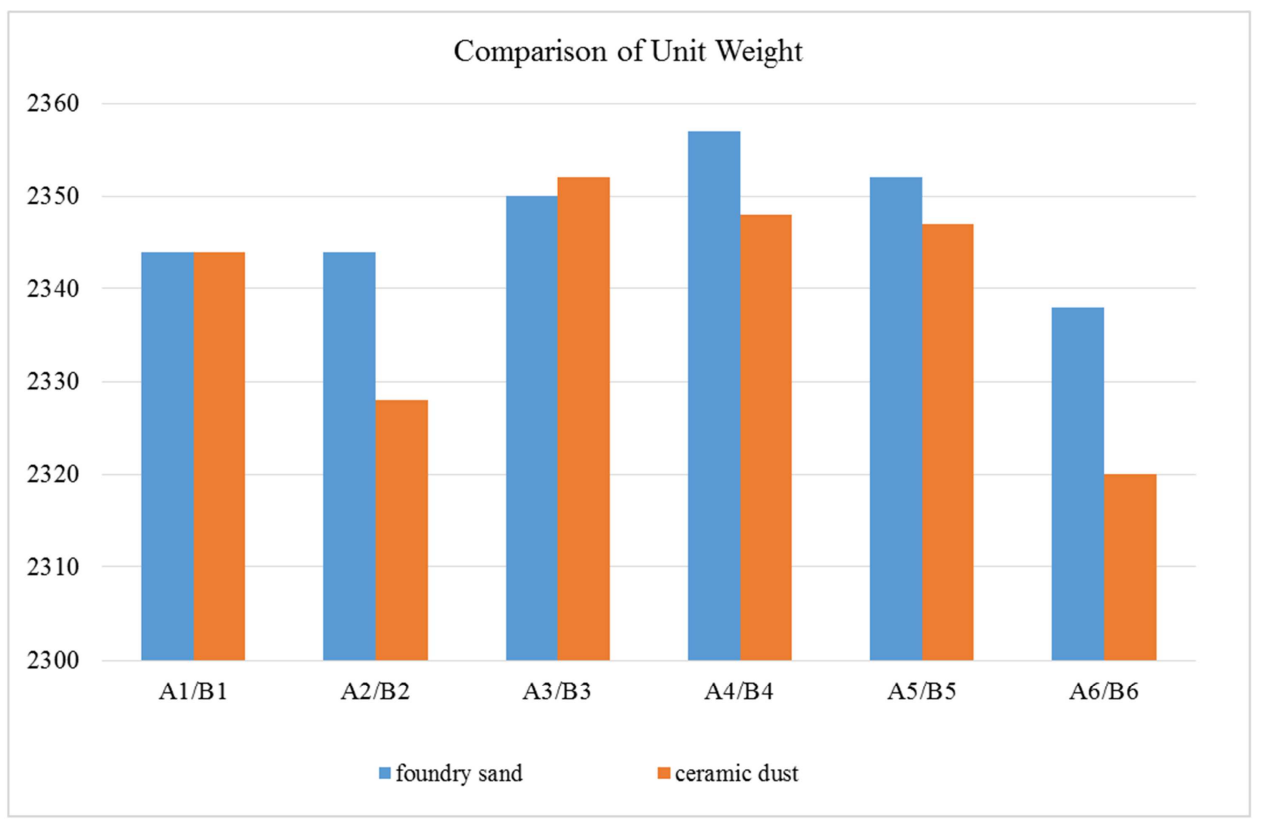

Figure 3. Comparison of Unit Weight of Mix Type A and B. 


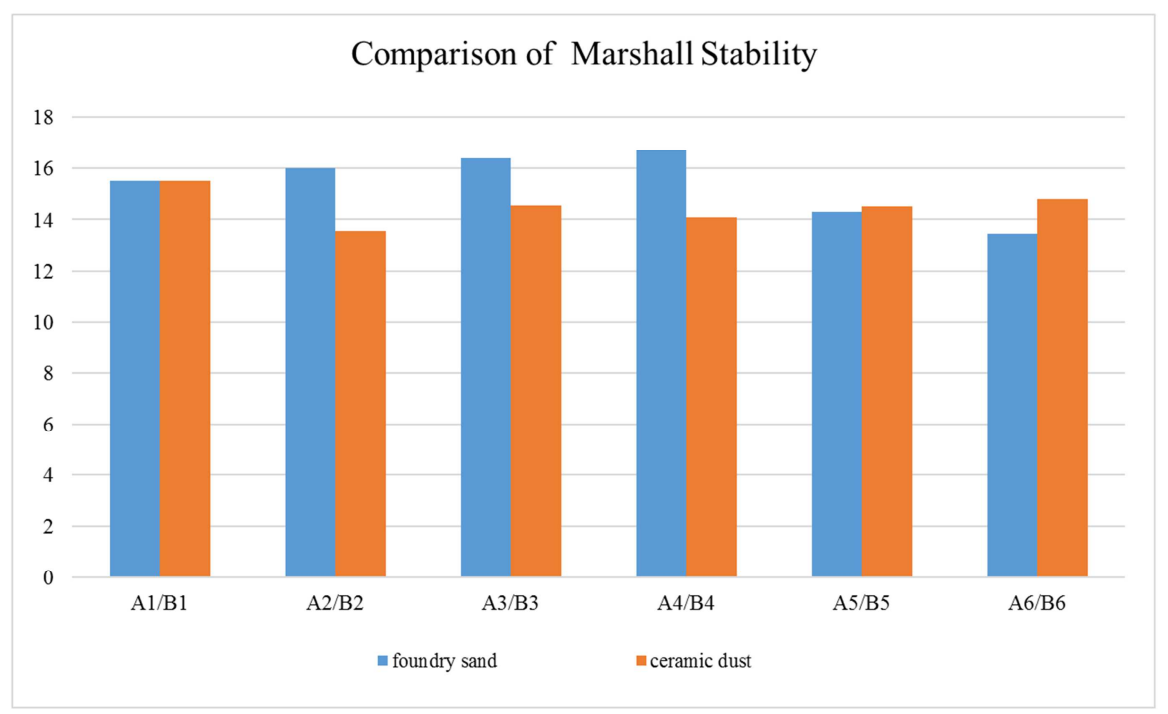

Figure 4. Comparison of Marshall Stability of Mix Type A and B.

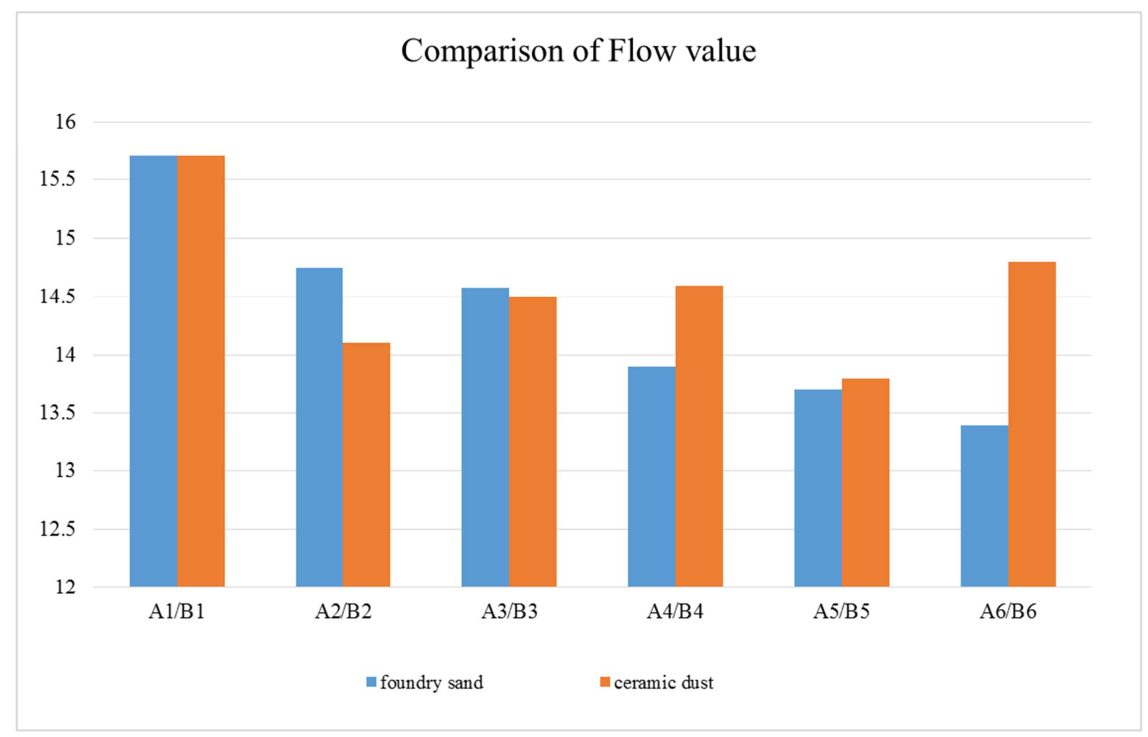

Figure 5. Comparison of Flow value of Mix Type A and B.

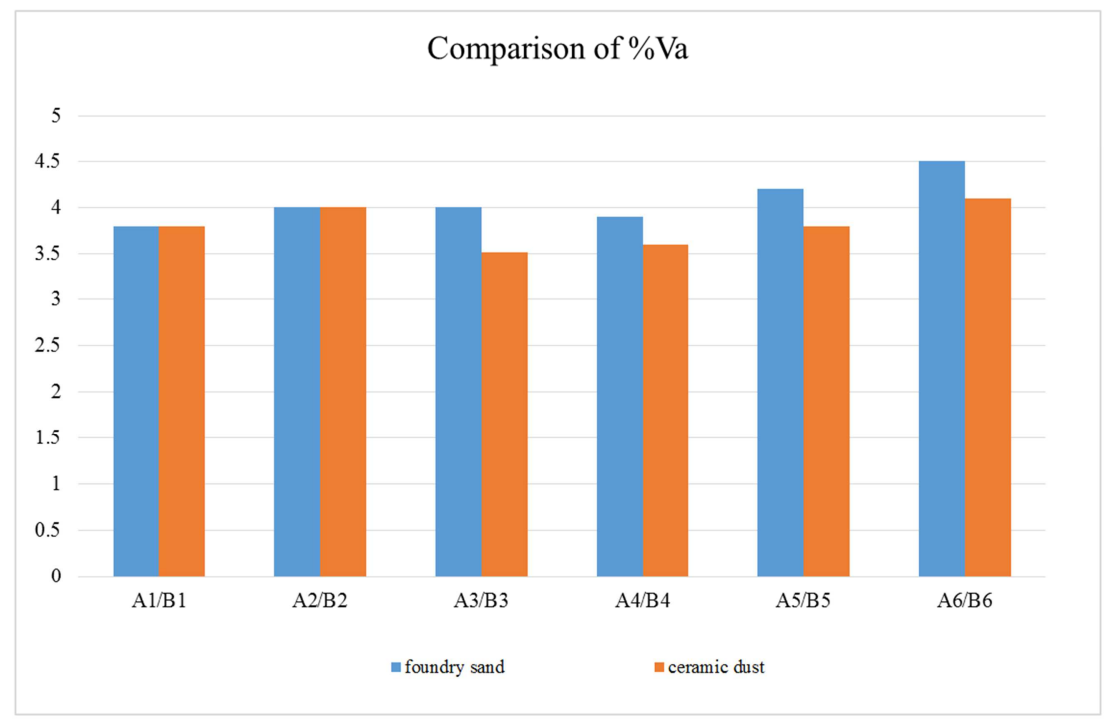

Figure 6. Comparison of\%Va of Mix Type A and B. 


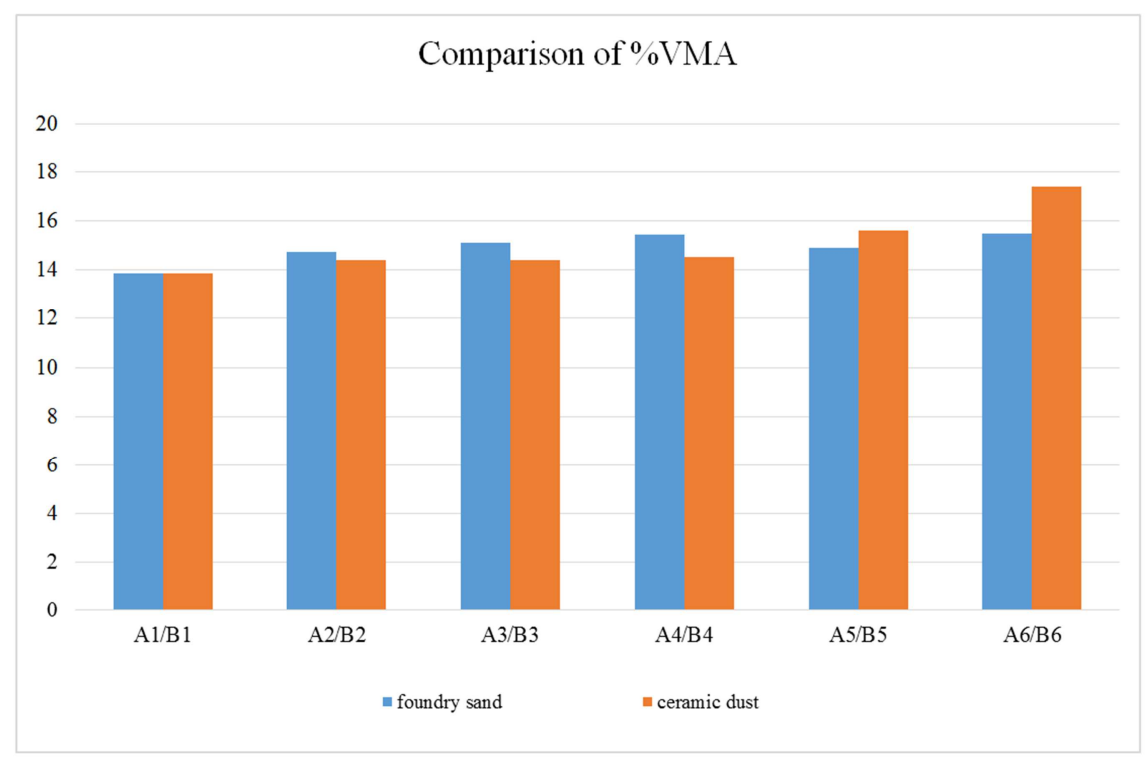

Figure 7. Comparison of \%VMA of Mix Type $A$ and $B$.

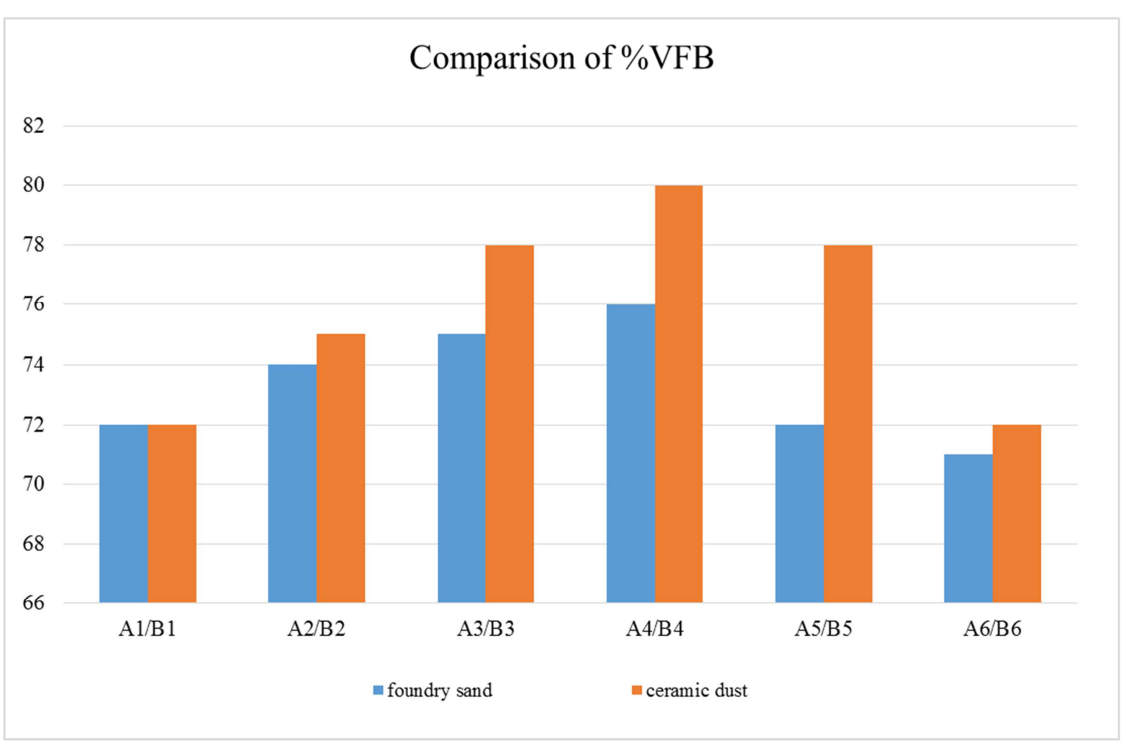

Figure 8. Comparison of $\%$ VFB of Mix Type $A$ and $B$.

\section{Analysis of Results}

From the Marshall Test results as shown in table 4 it is seen that with the increasing percentages of foundry sand OBC gradually increases. This actually happens due to the fineness of the foundry sand. From the results it is observed that for $50 \%$ replacement of foundry sand $\mathrm{OBC}$ value increases only 4\%. Unit weight and Marshall Stability value increases with the increasing percentage of foundry sand up to $30 \%$ and then decrease. From, table 3 it is found that for $30 \%$ replacement of foundry sand, unit weight is increased a negligible amount but the stability value increase about $7 \%$. This happens due to the inherent binding capacity of the foundry sand. The mix flow decreases as the foundry sand percent increases. When foundry sand percent increases from zero to $50 \%$, the flow value decreases from 15.7 (0.01 inch) to 13.4 (0.01 inch). Another important parameter is the air void that must be considered when designing bituminous Concrete mixture. For flexible pavement design generally the limiting value of air void is about $3 \%$ to $5 \%$ of the total mix volume. From the table 3 it is seen that increasing the foundry sand percent for all cases the percentage air voids remain within the limiting range. $\% \mathrm{VMA}$ and $\% \mathrm{VFB}$ are also within the limiting range for the all percentage replacement of foundry sand. The limiting value is given by the Asphalt Institute, 1997 [2]. For the increasing percentages of foundry sand Marshall Stiffness gradually increases because Marshall Stability value gradually increases and flow value decreases gradually.

Also from the test results as shown in Table 5 it has seen that with the increasing percentage of ceramic dust up to $30 \%$, OBC has decreased but it has increased only by $1.8 \%$ for $50 \%$ replacement of ceramic tile dust. Unit weight has 
increased up to $20 \%$ replacement, then decreases and Marshall Stability gradually increases after 20\% replacement of ceramic dust. Unit weight has decreased to a negligible amount but stability has increased to a significant amount. Flow value has decreased up to $20 \%$ replacement and then gradually increased. But it has remained within the allowable limit for medium traffic condition according to Asphalt Institute, 1997. The air void is another significant parameter which has considered during this test. The limiting value of air void is $3 \%$ to $5 \%$ for flexible pavement design and the values of air voids obtained from this experiment have remained within the permissible limit. \%VMA and \%VFB have also remained within the range. Marshall Stiffness has also increased with the increasing of percentage of ceramic tile dust as fine aggregate.

In accordance with the comparison curves unit weight is greater for the replacement of foundry sand than the replacement of ceramic tile dust as fine aggregate and this is due to the aggregate properties like specific gravity of foundry sand is greater than the specific gravity of tile dust. Marshall Stability has increased for foundry sand than tile dust up to $30 \%$ then gradually has increased for ceramic tile dust as the proportion of $\mathrm{SiO}_{2}, \mathrm{CaO}$ etc. are higher percentages in tile dust. Air voids and voids in mineral aggregate are larger percentage for foundry sand but void filled with bitumen are greater percentage for ceramic tile dust.

\section{Conclusions}

On the basis of experimental results of this study, the following conclusions are drawn.

1) Waste Foundry Sand is suitable for bituminous mixes from the consideration of aggregate properties.

2) $30 \%$ Replacement of waste foundry sand is recommended for flexible pavement design as this percentage satisfies the maximum Marshall Mix design criteria.

3) Ceramic tile dust is suitable for bituminous mixes from the consideration of aggregate properties.

4) With the increasing percentages of ceramic tiles dust the Marshall stability is gradually increasing. So, it is recommended to use higher percentages of replacement as fine aggregate.

\section{References}

[1] AASHTO 1983. "American Association of State Highway and Transportation Officials".
[2] "Mix Design Method for Asphalt Concrete and other Hot-Mix types" (1997) Manual series No. 2 (MS-2).

[3] Aravind K; Dash A. Industrial Waste in Highway Construction. pp 1-4.

[4] Benson, HC and Bradshaw, S. User Guideline For Foundry Sand In Green Infrastructure Construction. pp 1-17.

[5] Harihan, K; Kannabiran, E; Karthik, AR and Kumar, AP. 2018. Experimental Study Of Partial Replacement Of Aggregate By Waste Foundry Sand In Flexible Pavement. Special Issue ICETSST-April 2018, www.internationaljournalssrg.org.

[6] MORTH. "Ministry of Road Transportation Highways", 5th edition, page 178 .

[7] Suji D; Poovendran S and Prabhakar P. 2016. Environmental Study on Partial Replacement Of Waste Foundry Sand in Flexible Pavement, International Journal of Civil and Structural Engineering Research, vol. 4, Issue 1, Month: April 2016, pp: (188-197).

[8] Tambake, SO; Kumar, DN; and Manjunath, KR. 2014. Laboratory investigation on hot mix asphalt using reclaimed asphalt pavement for bituminous concrete mix, International Journal of Research in Engineering and Technology, Volume 03, Issue 06, Jun-2014.

[9] Bekir, A and Sevket, A. (2017). Comparative Evaluation of Replacement Foundry Sand with Mineral Fine Aggregates on HMA Properties. Volume 7, Issue 3-July 2017, www.tojsat.net.

[10] Bhavin, K. V. \& Bhatt, M. R. (2016). A study on effect of waste ceramic tiles in flexible pavement.

[11] Singh, A. \& Patel, M. (2015). A study on effect of ceramic waste in bituminous concrete mixes.

[12] Trogal, F. P. \& Jalali, S. (2009). Compressive strength and durability properties of ceramic wastes based concrete.

[13] Zimbili, o., Salim W., \& Nadambuki Jm. (2014). A Review on the Usage of Ceramic Wastes in Concrete production.

[14] Sadek, D. M., Hanan, A. \& Nouhy, EI. (2013). Properties of paving units incorporating crushed ceramic.

[15] Chandra, S. \& Choudhary, R. (2010). Performance Characteristics of Bituminous Concrete with Industrial Wastes as Filler. Journal of Materials in Civil Engineering, DOI: 10.1061/(ASCE)MT.1943-5533.0000125

[16] Lulseged, A., Hemantharaja, K., Prasad, C. V. S. R. (2016). Study on using Plastic Coated Aggregate in Bituminous Mix for Flexible Pavement. International Journal of Scientific Engineering \& Technology Research. ISSN 2319-8885, Vol. 05, Issue. 05, February-2016, Pages: 0933-0936. 